\title{
Effect of calcium propionate and monensin on in vitro digestibility and gas production
}

\author{
Amada Isabel Osorio-Teran', Germán David Mendoza-Martínez ${ }^{2}$, Luis Alberto Miranda-Romero³, \\ Daniel Martínez-Gomez², Pedro Abel Hernández-García ${ }^{4}$, José Antonio Martínez-García²
}

\footnotetext{
${ }^{1}$ Universidad Autónoma Metropolitana, Xochimilco, Doctorado en Ciencias Biológicas y de la Salud, Ciudad de México, México.

${ }^{2}$ Universidad Autónoma Metropolitana, Xochimilco, Departamento de Producción Agrícola y Animal, Ciudad de México, México.

3 Universidad Autónoma Chapingo, Posgrado en Producción Animal, Texcoco, Estado de México, México.

${ }^{4}$ Universidad Autónoma del Estado de México, Amecameca, Estado de México, México.
}

\begin{abstract}
An evaluation of the effects of monensin and calcium propionate on the in vitro kinetics of gas production, digestibility, carbon dioxide, and minor gas production on different days was performed using the ruminal fluid from eight Suffolk lamb donors, after receiving additives for 1, 10, and 20 days. Treatments consisted of a control ration of $40 \%$ grain; $30 \mathrm{mg} / \mathrm{kg}$ of monensin in a diet with $40 \%$ grain; $10 \mathrm{~g} / \mathrm{kg}$ calcium propionate in a diet with $30 \%$ grain; and the combination of both additives in a diet with $30 \%$ grain. The gas production was measured up to $72 \mathrm{~h}$ of incubation and all incubation procedures were repeated three times on days 1,10 , and 20. On incubation day 20, the volume and production of methane and minor gases were measured. There was an interaction between calcium propionate and monensin for maximum gas production, in vitro dry matter digestibility (IVDMD), carbon dioxide, and minor gases. Monensin reduced gas production on days 1 and 20 , whereas calcium propionate increased gas production $(\mathrm{Vm})$ on day 1 . The rate of gas production (s) was reduced by calcium propionate on day 1 and by the combination of additives on day 10. Lag time was reduced by monensin on day 10; however, it declined linearly with the feeding time of the additives. Monensin had no effect on IVDMD (62.29 vs. 62.24\%), while calcium propionate increased the IVDMD (60.00 vs. 64.53\%). The inclusion of monensin increased $\mathrm{CO}_{2}$; however, the combination of monensin and calcium propionate had no effect on $\mathrm{CO}_{2}$ production. Monensin reduced methane (25.37 vs. $\left.20.29 \%\right)$ and increased $\mathrm{CO}_{2}$. None of the additives showed consistent effects on the kinetic parameters of in vitro gas production over time. The treatments with monensin and calcium propionate showed a significant reduction in methane production, with a higher fermentation efficiency since the IVDMD was increased. Both additives are a strategy to consider to reduce methane emissions without affecting the ruminal fermentation.
\end{abstract}

Key Words: additive feeding, carbon dioxide, ionophore, methane, rumen fermentation

\section{Introduction}

To maximize the production efficiency and reduce metabolic problems, it is a common practice to include feed additives in rations for high-producing animals. Certain products could have more advantages, such as reducing the greenhouse gas production without affecting animal performance. Ionophores are an alternative to reduce ruminal methane production (Ellis et al., 2012); monensin is a predominant antibiotic

Received: January 14, 2016

Accepted: November 6, 2016

*Corresponding author: gmendoza@correo.xoc.uam.mx

http://dx.doi.org/10.1590/S1806-92902017000400011

How to cite: Osorio-Teran, A. I.; Mendoza-Martínez, G. D.; Miranda-Romero, L. A.; Martínez-Gomez, D.; Hernández-García, P. A. and Martínez-García, J. A. 2017. Effect of calcium propionate and monensin on in vitro digestibility and gas production. Revista Brasileira de Zootecnia 46(4):348-353.

Copyright (C) 2017 Sociedade Brasileira de Zootecnia. This is an Open Access article distributed under the terms of the Creative Commons Attribution License (http://creativecommons.org/licenses/by/4.0/), which permits unrestricted use, distribution, and reproduction in any medium, provided the original work is properly cited. given to ruminants (Kim et al., 2014a), although its use is restricted in many countries. Alternatively, the use of calcium propionate may change the acetate to propionate ratio (Ferraro et al., 2009), allowing for a reduction in the grain level of the ration (Lee et al., 2012). The combination of both additives could reduce methane emissions (Moss et al., 2000; Wang et al., 2009) without affecting ruminant productivity and could be an interesting feeding option.

It is well known that monensin increases the production of propionate (Ellis et al., 2012); therefore, its combination with a calcium propionate could be a better alternative for reducing methane emissions. It is important to have a previous evaluation of the ruminal additives before their use in production that can be performed with an in vitro gas production technique, which is a precise and fast procedure (Getachew et al., 2004). Therefore, the objective of this study was to evaluate monensin, with or without calcium propionate, in complete diets in which grain was reduced to $100 \mathrm{~g} / \mathrm{kg}$ using in vitro gas techniques to estimate $\mathrm{CO}_{2}$ and minor gas production $\left(\mathrm{CH}_{4}, \mathrm{~N}_{2}, \mathrm{H}_{2}\right.$ and others), and 
incubating at different days of the additive adaptation of the inoculum donors.

\section{Material and Methods}

The present investigation was performed in Texcoco, Estado de Mexico, Mexico (19 $29^{\prime} 23^{\prime \prime} \mathrm{N}$ and 98 53'37"W), following the guidelines of the local Academic Committee, under the Law of Animal Production of the State of Mexico.

Eight male Suffolk sheep (24 kg body weight, six months old) were ruminally cannulated and divided into four treatments; then, they were fed the experimental diets with or without additives (Table 1) and used as donors of rumen fluid. The animals were housed and fed in individual pens. Before the beginning of the experiment, the animals were fed a 50:50 (silage:concentrate) ration. Then, they were adapted to the experimental rations gradually during a 10-day period. The experiment lasted twenty days after the adaptation period. Sampling was performed three times during the experimental period on days 1,10 , and 20 , in which the animals were fed diets with additives.

The sheep were fed $1.2 \mathrm{~kg}$ of an experimental diet twice daily (at 08.00 and $15.00 \mathrm{~h}$ ) and water was provided ad libitum. Experimental diets were offered over 20 days and ruminal fluid was collected on days 1, 10, and 20 .

The dietary treatments consisted of a control ration with $40 \%$ grain; $30 \mathrm{mg} / \mathrm{kg}$ of monensin sodium (Rumensin $200 \mathrm{~g}$ Elanco Animal Health, Mexico D.F.) in a diet with $40 \%$

Table 1 - Experimental diets and chemical compositions

\begin{tabular}{|c|c|c|c|c|}
\hline & Control & $\mathrm{Ca}-\mathrm{Pr}$ & Monensin & $\begin{array}{c}\mathrm{Ca}-\mathrm{Pr}+ \\
\text { Monensin }\end{array}$ \\
\hline \multicolumn{5}{|l|}{ Ingredient (g/kg) } \\
\hline Corn grain & 400 & 309.5 & 400 & 309.2 \\
\hline Corn gluten & 95 & 100 & 95 & 100 \\
\hline Sugarcane molasses & 100 & 110 & 110 & 110 \\
\hline Corn stover & 380 & 445 & 369.7 & 445 \\
\hline Urea & 10 & 10.5 & 10 & 10.5 \\
\hline Buffer $^{1}$ & 10 & 10 & 10 & 10 \\
\hline Minerals $^{2}$ & 5 & 5 & 5 & 5 \\
\hline Calcium propionate ${ }^{3}$ & 0 & 10 & 0 & 10 \\
\hline Monensin & 0 & 0 & 0.3 & 0.3 \\
\hline \multicolumn{5}{|c|}{ Chemical composition $(\mathrm{g} / \mathrm{kg})$} \\
\hline Dry matter & 880.4 & 868.8 & 888.4 & 878 \\
\hline Organic matter & 838.0 & 845.0 & 846.4 & 843.5 \\
\hline Crude protein & 148.6 & 146.1 & 148.4 & 147.1 \\
\hline Ether extract & 25.5 & 25.0 & 24.5 & 28 \\
\hline Neutral detergent fiber & 307.9 & 321.5 & 301.2 & 332.5 \\
\hline \multicolumn{5}{|c|}{ 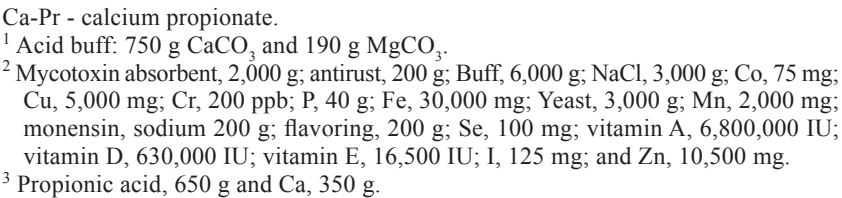 } \\
\hline
\end{tabular}

grain; $10 \mathrm{~g} / \mathrm{kg}$ calcium propionate (65\%, Paniplus Mexico) in a diet with $30 \%$ grain; and $30 \mathrm{mg} / \mathrm{kg}$ of monensin sodium plus $10 \mathrm{~g} / \mathrm{kg}$ calcium propionate in a diet with $30 \%$ grain. Diets were analyzed for dry matter, organic matter, crude protein, and ether extract according to AOAC (1990) and neutral detergent fiber procedures (Van Soest et al., 1991) (Table 1).

Rumen fluid was collected $(100 \mathrm{~mL})$ using a Tygon tube connected to a vacuum pump and a 1000-mL Erlenmeyer flask. Rumen fluid was transported to the laboratory in sterile plastic containers $(150 \mathrm{~mL})$ at $39{ }^{\circ} \mathrm{C}$ and the rumen fluid obtained from both donors for each treatment was obtained individually and then mixed for later use.

Ninety millilitres of reduced mineral solution and rumen fluid $(9: 1)$ were added to amber flasks $(120 \mathrm{~mL})$ containing $0.5 \mathrm{~g}$ of each diet and incubated under anaerobic conditions in a water bath at $39{ }^{\circ} \mathrm{C}$. Each incubation was performed in triplicate, using each experimental diets as a substrate. Gas production was measured up to $72 \mathrm{~h}$ of incubation using the in vitro gas production procedure described by Menke and Steingas (1988).

The reduced mineral solution per liter of solution contained $\mathrm{Ca}_{2} \mathrm{CO}_{3}(4 \mathrm{~g}) ; \mathrm{K}_{2} \mathrm{HPO}_{4}(0.45 \mathrm{~g}) ; \mathrm{KH}_{2} \mathrm{PO}_{4}(0.45 \mathrm{~g})$; $\left(\mathrm{NH}_{4}\right)_{2} \mathrm{SO}_{4}(0.45 \mathrm{~g}) ; \mathrm{NaCl}(0.90 \mathrm{~g}) ; \mathrm{MgSO}_{4}(0.18 \mathrm{~g}) ; \mathrm{CaCl}_{2}$ $(0.07 \mathrm{~g}) ; \mathrm{Na}_{2} \mathrm{SO}_{4}(0.5 \mathrm{~g})$; L-cysteine $(0.5 \mathrm{~g})$; distilled water $(50 \mathrm{~mL}) ; \mathrm{NaOH} 1 \mathrm{~N}(2 \mathrm{~mL})$; and one drop of rezarsurin (Ferraro et al., 2009).

After incubation ( $72 \mathrm{~h}$ ), the residual was filtered to determine in vitro dry matter digestibility. All incubation procedures were repeated three times on days 1,10 , and 20. Gas volume data and incubation time were used to obtain the parameters of the kinetics of gas production: maximum volume of gas produced $(\mathrm{Vm})$, lag phase (L), and rate of gas production (S), using the logistic model $\mathrm{Vo}=\mathrm{Vm} /\left(1+\exp ^{\left(2-4 * \mathrm{~s}^{*}(\mathrm{t} \mathrm{L})\right.}\right)$ described by Pitt et al. (1999).

On incubation day 20, the volume and production of $\mathrm{CO}_{2}$ after $24 \mathrm{~h}$ of fermentation were measured volumetrically, estimating the methane and minor gases by the difference in these values (Singh and Mohini, 1999). Thirty millilitres of reduced mineral solution and rumen fluid (2:1) were added into amber flasks $(60 \mathrm{~mL})$ containing $0.25 \mathrm{~g}$ of the each diet. Gas production was measured at 0 , 6,12 , and $24 \mathrm{~h}$ with a $150-\mathrm{mL}$ glass syringe to determine the production of $\mathrm{CO}_{2}$ and minor gases. Flasks $(60 \mathrm{~mL})$ were prepared with $40 \mathrm{~mL} 1 \mathrm{~N}$ potassium hydroxide to capture the gas and then titrated with $0.55 \mathrm{~N}$ hydrochloric acid using $1 \mathrm{~mL}$ potassium hydroxide, one drop of barium chloride, and one drop of rezarsurine to determine $\mathrm{CO}_{2}$ $\mathrm{mmol} / \mathrm{g}=(\mathrm{B}-\mathrm{S}) \times \mathrm{N} \times 1000 / 2$ (weight sample), in which $\mathrm{B}=\mathrm{mL} \mathrm{HCl}$ used in the blank, $\mathrm{S}=\mathrm{mL} \mathrm{HCl}$ used in the 
sample $(\mathrm{mL})$, and $\mathrm{N}=$ normality of $\mathrm{HCl}$. The percentage of $\mathrm{CO}_{2}$ was estimated as a function of the total maximum volume.

Results were analyzed as a completely randomized design with a $2 \times 2$ factorial arrangement (factors were the additive source at two levels) with the repeated measure procedure (days 0, 10, and 20). A Tukey's test was used to compare treatment means using the JMP software (Sall et al., 2012).

The model included the fixed effects of treatments and its interaction. Data were analyzed with the repeated measures over time (Littell et al., 1998) according to the model:

$$
\begin{gathered}
\text { Yijklm }=\mu+\alpha_{i}+\tau_{k}+(\alpha \tau)_{i k}+d_{k}(i j)+\gamma m+(\alpha \gamma) i m+ \\
(\tau \gamma) k m+(\alpha \tau \gamma) i k m+\varepsilon i j k l m,
\end{gathered}
$$

in which Yijklm is the dependent variable; $\mu$ is the overall mean; $\alpha_{i}$ is the fixed effect of calcium propionate $(i=1,2)$; $\tau_{k}$ is the fixed effect of monensin level $(k=1,2) ;(\alpha \tau)_{i k}$ is the calcium propionate $\times$ monensin; $\mathrm{d}_{k}(i j)$ is the random effect of the $k$-th subject (animal) nested within treatment (i.e., the calcium propionate $\times$ monensin level interaction); $\gamma m$ is the fixed effect of the day of evaluation $(m=1,2,3) ;(\alpha \gamma) i m$ is the $\mathrm{Ca}-\mathrm{Pr} \times$ day of evaluation interaction; $(\tau \gamma) \mathrm{km}$ is the monensin level $\times$ day of evaluation interaction; $(\alpha \tau \gamma) i \mathrm{~km}$ is the $\mathrm{Ca}-\mathrm{Pr} \times$ monensin $\times$ day of evaluation interaction; and sijklm is the random error.

\section{Results}

There was an interaction $(\mathrm{P}<0.05)$ between calcium propionate and monensin for maximum gas production $(\mathrm{Vm})$, in vitro dry matter digestibility (IVDMD), $\mathrm{CO}_{2}$, and methane and minor gases (Table 2). Monensin reduced $\mathrm{Vm}$ on days 1 and $20(\mathrm{P}<0.05)$, whereas calcium propionate increased $\mathrm{Vm}$ on day $1(\mathrm{P}<0.05)$. The rate of gas production was reduced by calcium propionate on day 1 by 1 and by the combination of additives on day $10(\mathrm{P}<0.05)$. Lag time was reduced by monensin on day $10(\mathrm{P}<0.01)$ and declined linearly with adaptation time (Figure 1).

Monensin had no effect on in vitro digestibility (62.29 vs. $62.24 \%$ ), whereas calcium propionate increased this value $(60.00$ vs. $64.53 \%)(\mathrm{P}<0.01)$. There was a linear increase in digestibility according to the adaptation time $(\mathrm{P}<0.0001)$ (Figure 2).

The inclusion of monensin increased $\mathrm{CO}_{2}$ (74.62 vs. $79.70 \%$ ), whereas the combination of monensin and calcium propionate avoided this increment (interaction $\mathrm{P}<0.008$ ). Methane production was reduced with monensin (25.37 vs. $20.29 \%$ ), whereas its combination with calcium propionate had no effect (Table 2). Likewise, calcium propionate did not affect methane production. A longer duration of additive feeding improved the digestibility,

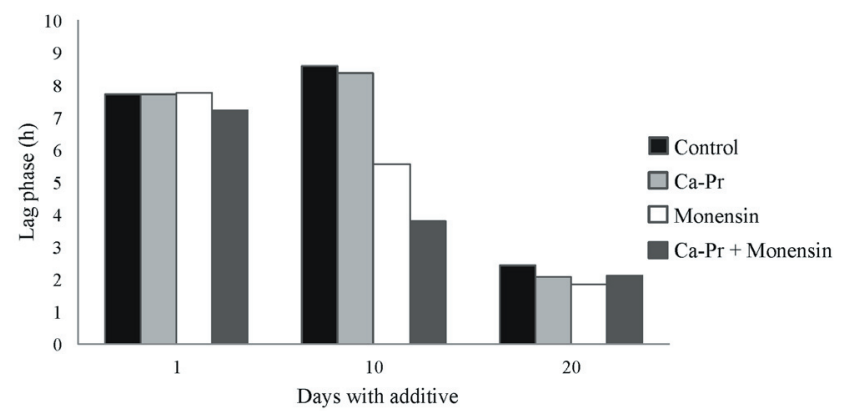

Figure 1 - Effect of day with feed additives on the lag time during in vitro gas production.

Table 2 - Effect of monensin and calcium propionate on in vitro gas production kinetics, digestibility, methane, and carbon dioxide

\begin{tabular}{|c|c|c|c|c|c|c|c|}
\hline \multicolumn{2}{|c|}{ Days with additive } & \multirow{2}{*}{$\begin{array}{l}\text { Control } \\
299.58 b\end{array}$} & \multirow{2}{*}{$\frac{\mathrm{Ca}-\mathrm{Pr}}{330.20 \mathrm{a}}$} & \multirow{2}{*}{$\frac{\text { Monensin }}{235.98 \mathrm{c}}$} & \multirow{2}{*}{$\frac{\text { Ca-Pr }+ \text { Monensin }}{284.63 b}$} & \multirow{2}{*}{$\begin{array}{c}\text { SEM } \\
7.48\end{array}$} & \multirow{2}{*}{$\frac{\text { P-value }}{0.0001}$} \\
\hline 1 & Vm (mL/g) & & & & & & \\
\hline & $\mathrm{s}(\mathrm{mL} / \mathrm{g})$ & $0.035 \mathrm{a}$ & $0.029 b$ & $0.031 \mathrm{ab}$ & $0.032 \mathrm{ab}$ & 0.0009 & 0.002 \\
\hline & $\mathrm{L}(\mathrm{h})$ & $7.72 \mathrm{a}$ & $7.73 \mathrm{a}$ & $7.75 \mathrm{a}$ & $7.22 \mathrm{a}$ & 0.51 & 0.86 \\
\hline & IVDMD (\%) & $48.61 \mathrm{~b}$ & $52.19 \mathrm{ab}$ & $48.55 b$ & $57.69 \mathrm{a}$ & 2.13 & 0.0002 \\
\hline \multirow[t]{4}{*}{10} & $\mathrm{Vm}(\mathrm{mL} / \mathrm{g})$ & $312.22 \mathrm{a}$ & $324.20 \mathrm{a}$ & $315.90 \mathrm{a}$ & $337.52 \mathrm{a}$ & 9.15 & 0.24 \\
\hline & $\mathrm{s}(\mathrm{mL} / \mathrm{g})$ & $0.034 \mathrm{ab}$ & $0.036 \mathrm{a}$ & $0.034 \mathrm{a}$ & $0.031 \mathrm{~b}$ & 0.0007 & 0.0009 \\
\hline & $\mathrm{L}(\mathrm{h})$ & $8.59 \mathrm{a}$ & $8.36 \mathrm{a}$ & $5.56 \mathrm{~b}$ & $3.78 \mathrm{c}$ & 0.37 & 0.0001 \\
\hline & IVDMD (\%) & $61.39 \mathrm{a}$ & $61.47 \mathrm{a}$ & $56.55 \mathrm{~b}$ & $61.05 \mathrm{a}$ & 0.73 & 0.020 \\
\hline \multirow[t]{6}{*}{20} & $\mathrm{Vm}(\mathrm{mL} / \mathrm{g})$ & $300.75 a$ & $282.67 \mathrm{ab}$ & $264.90 \mathrm{~b}$ & $302.02 \mathrm{a}$ & 7.14 & 0.004 \\
\hline & $\mathrm{s}(\mathrm{mL} / \mathrm{g})$ & $0.040 \mathrm{a}$ & $0.038 \mathrm{a}$ & $0.041 \mathrm{a}$ & $0.041 \mathrm{a}$ & 0.001 & 0.09 \\
\hline & $\mathrm{L}(\mathrm{h})$ & $2.43 \mathrm{a}$ & $2.07 \mathrm{a}$ & $1.87 \mathrm{a}$ & $2.11 \mathrm{a}$ & 0.19 & 0.26 \\
\hline & IVDMD (\%) & $72.83 b$ & $77.25 \mathrm{a}$ & $72.11 \mathrm{~b}$ & $77.52 \mathrm{a}$ & 0.65 & 0.0001 \\
\hline & $\mathrm{CO}_{2}(\%)$ & $71.65 \mathrm{~b}$ & $77.60 \mathrm{ab}$ & $82.09 \mathrm{a}$ & $77.31 \mathrm{ab}$ & 2.38 & 0.045 \\
\hline & $\mathrm{CH}_{4}(\%)$ & $28.35 \mathrm{a}$ & $22.39 \mathrm{ab}$ & $17.90 \mathrm{~b}$ & $22.68 \mathrm{ab}$ & 2.38 & 0.045 \\
\hline
\end{tabular}
production

Ca-Pr - calcium propionate; SEM - standard error of the mean; Vm - maximum volume of gas produced; s - rate of gas production; L - lag phase; IVDMD - in vitro dry matter digestibility.

Means with different letters are statistically different $(\mathrm{P}<0.05)$. 
rate of gas production, and lag time parameters of the lambs (Figure 3 and Table 3).

\section{Discussion}

Because of the antibiotic nature of monensin, we expected it to have an inhibitory effect on all kinetic parameters of gas production and digestibility. The effect of monensin is a function of the dosage. Two in vitro experiments reported that monensin decreased gas production and that the doses were higher than those used in animal feeds (Smith, 2010; Kim et al., 2014a). In contrast, Singh and Mohani (1999) did not find any effect on in vitro gas production using 50 or $100 \mathrm{mg} / \mathrm{d}$ of monensin in rumen fluid donors. The lack of effects of monensin in this study agrees with molecular studies that did not reveal large shifts in the relative abundance of Gram-positive bacteria in response to monensin from in vivo samples (Kim et al., 2014b).

The absence of effects on in vitro dry matter agrees with findings of Singh and Mohani (1999), without changes in in vivo organic and dry matter digestibility. Smith (2010) reported that the in vitro digestibility was not affected by monensin, even when microbial growth was depressed. Similar results were reported by Garcia et al. (2000), Gonzales et al. (2009), and Meyer et al. (2009) with different levels of monensin (30 mg/kg or $90 \mathrm{mg} / \mathrm{kg} \mathrm{DM})$. Schelling (1984) concluded that monensin have no effect

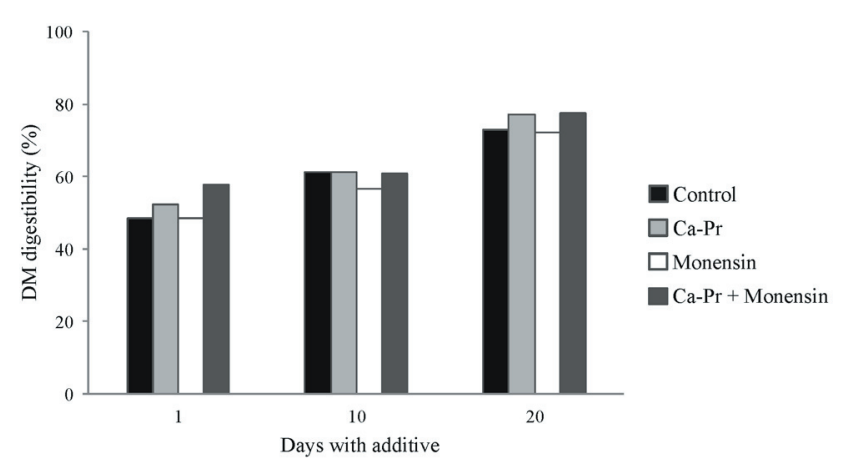

Figure 2 - Effect of adaptation time on digestibility. on cellulose digestibility when animals were adapted for 21 days, which agrees with the current study, because sheep had more time receiving the ionophore. Consequently, the linear response on time confirms the adaptation for all additives on day 20 .

It is not clear why the addition of calcium propionate increased in vitro gas production; its inclusion probably produced a change in $\mathrm{pH}$ and osmotic pressure. Greater amylolytic activity has been observed in similar conditions (Mendoza et al., 1999), because the dissociation of calcium propionate contributes to the production of volatile fatty acids. Lee et al. (2012) reported that the addition of calcium propionate in diets for lambs resulted in a higher proportion of propionic acid in lambs. Miranda et al. (2016) did not find the stimulatory effect of calcium propionate on the volume of gas production with similar grain levels. Other glycogenic substrates, such as glycerol, reduced in vitro gas production (Young et al., 2011; Ferraro et al., 2009); however, the kinetics of degradation was affected by the adaptation period. Young et al. (2011) observed that after
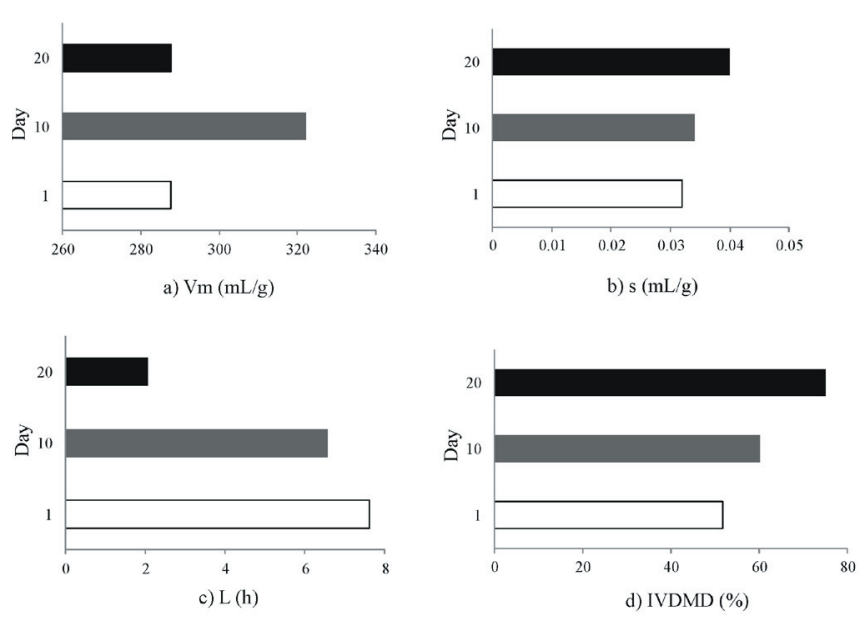

Data are presented repeated at time by treatment: a) maximum volume of gas $(\mathrm{Vm})$; b) rate of gas production (s); c) lag phase (L); and d) in vitro dry matter digestibility (IVDMD).

Figure 3 - Effect of time (days 1, 10, and 20) on fermentation kinetics variables and IVDMD.

Table 3 - Effect of treatments and day on fermentation kinetics variables

\begin{tabular}{|c|c|c|c|c|c|c|c|c|c|c|c|c|}
\hline \multirow{2}{*}{ Item } & \multicolumn{4}{|c|}{ Treatment $(\mathrm{T})$} & \multicolumn{3}{|c|}{ Day (D) } & \multirow{2}{*}{$\mathrm{P}$-value } & \multirow{2}{*}{ SEM } & \multicolumn{3}{|c|}{ Effect } \\
\hline & Control & Monensin & $\mathrm{Ca}-\mathrm{Pr}$ & $\mathrm{Ca}-\mathrm{Pr}+\mathrm{Monensin}$ & 1 & 10 & 20 & & & $\mathrm{~T}$ & $\mathrm{D}$ & $\mathrm{T} \times \mathrm{D}$ \\
\hline $\operatorname{Vm}(\mathrm{mL} / \mathrm{g})$ & $304.38 \mathrm{a}$ & $272.20 \mathrm{~b}$ & $312.30 \mathrm{a}$ & $308.06 \mathrm{a}$ & $287.61 \mathrm{~b}$ & $322.47 \mathrm{a}$ & $287.62 b$ & 0.003 & 17.28 & 0.006 & 0.002 & 0.03 \\
\hline $\mathrm{s}(\mathrm{mL} / \mathrm{g})$ & $0.03 \mathrm{a}$ & $0.03 \mathrm{a}$ & $0.035 \mathrm{a}$ & $0.035 \mathrm{a}$ & $0.032 \mathrm{~b}$ & $0.034 \mathrm{~b}$ & $0.040 \mathrm{a}$ & 0.005 & 0.002 & 0.65 & $<0.0001$ & 0.19 \\
\hline $\mathrm{L}(\mathrm{h})$ & $6.18 \mathrm{a}$ & $5.06 \mathrm{a}$ & $6.05 \mathrm{a}$ & $4.37 \mathrm{a}$ & $7.60 \mathrm{a}$ & $6.57 \mathrm{a}$ & $2.07 \mathrm{~b}$ & $<0.001$ & 1.14 & 0.05 & $<0.0001$ & 0.08 \\
\hline IVDMD (\%) & $60.94 b c$ & $59.05 \mathrm{c}$ & $63.63 \mathrm{ba}$ & $65.42 \mathrm{a}$ & $51.76 \mathrm{c}$ & $60.10 \mathrm{~b}$ & $74.93 \mathrm{a}$ & $<0.001$ & 2.38 & 0.002 & $<0.0001$ & 0.25 \\
\hline
\end{tabular}

Ca-Pr - calcium propionate; SEM - standard error of the mean; Vm - maximum volume of gas produced; s - rate of gas production; L - lag phase; IVDMD - in vitro dry matter digestibility.

Means with different letters are statistically different $(\mathrm{P}<0.05)$ 
an adaptation, ruminal bacteria can easily ferment glycerol, whereas ruminal fluid from unadapted donors shows a considerably longer lag phase.

The estimation indicates that monensin reduced methane production by $10 \%$ in comparison with the control, which is similar to that reported in other studies (Guan et al., 2006; Johnson et al., 2009; Ellis et al., 2012), and can be explained by the effect on bacteria susceptible to ionophores, which are the main producers of acetate, butyrate, and $\mathrm{H}_{2}$, and $\mathrm{CO}_{2}$ substrates for methanogenesis (Moss et al., 2000). Singh and Mohani (1999) reported reductions of methane between 23 and $28 \%$ with slightly higher doses than those reported in this experiment. In contrast, Kim et al. (2014a) observed a dramatic reduction in methane (53\%) with doses not biologically useful for animals.

The addition of calcium propionate could reduce methane production because it is metabolized into propionic acid. The formation of propionate requires hydrogen and does not produce $\mathrm{CO}_{2}$ (D'Mello, 2000); however, this effect was not observed by Miranda et al. (2016), who studied grain level and calcium propionate.

Callaway and Martin (1996) incubated corn with organic acid plus monensin ( $5 \mathrm{mg} / \mathrm{kg})$, which increased $\mathrm{CO}_{2}$ production because of lactate fermentation to propionate via the succinate propionate pathway, with carbon dioxide as the end-product. It has been demonstrated that ionophores select for major propionate producers such as Selenomonas rumiantium, which ferment lactate using that pathway (Mackie et al., 1984).

There is evidence that monensin reduces Gram-positive bacteria groups, rumen protozoa, and fungi, whereas some bacteria strains are more sensitive than others and some are resistant, mainly due to the structure of the cell wall of organisms (Ellis et al., 2012, Mendoza et al., 1993). Research indicates that monensin may decrease the number of protozoa by 4 to $63 \%$ (Shelling, 1984).

\section{Conclusions}

The use of monensin and calcium propionate during a given period of time shows an improved in vitro dry matter digestibility, reducing methane production, resulting in a better fermentative efficiency. Both additives are a viable nutritional strategy for the reduction of Greenhouse gases such as methane.

\section{Acknowledgments}

The authors express their gratitude to the Universidad Autónoma Chapingo, as well as its experimental farm for all the facilities granted for the accomplishment of this work.

\section{References}

AOAC - Association of Official Analytical Chemists. 1990. Official methods of analysis 15th ed. Association of Official Analytical Chemists, Arlington, VA.

Callaway, T. R. and Martin, S. A. 1996. Effects of organic acid and monensin treatment on in vitro mixed ruminal microorganism fermentation of cracked corn. Journal of Animal Science 74:1982-1989.

D'Mello, F. P. J. 2000. Farm animal metabolism and nutrition. 1st ed. CABI Publishing, New York. USA.

Ellis, J. L.; Dijkstra, J.; Bannink, A.; Kebreab, E.; Hook, S. E.; Archibeque, S. and Franc, J. 2012. Quantifying the effect of monensin dose on the rumen volatile fatty acid profile in highgrain-fed beef cattle. Journal of Animal Science 90:2717-2726.

Ferraro, M. S.; Mendoza, G. D.; Miranda, L. A. and Gutiérrez, C. G. 2009. In vitro gas production and ruminal fermentation of glycerol, propylene glycol and molasses. Animal Feed Science and Technology 154:112-118

García, C. C. G.; Mendoza, G. D.; González, S. M.; Cobos, M.; Ortega, M. E. and Ramírez, R. L. 2000. Effect of a yeast culture Saccharomyces cerevisiae and monensina on ruminal fermentation and digestion in sheep. Animal Feed Science and Technology 83:165-170.

Getachew, G.; DePeters, E. J. and Robinson, P. H. 2004. In vitro gas production provides effective method for assessing ruminant feeds. California Agriculture 58:54-58.

Gonzáles, M. M. L.; Kawas, R.; García, R.; González, C.; Aguirre, J.; Hernández, G.; Fimbres, H.; Picón, F. J. and Lud, C. D. 2009. Nutrient intake, digestibility, mastication and ruminal fermentation of Pelibuey lambs fed finishing diets with ionophore (monensin or lasalocid) and sodium malate. Small Ruminant Research 83:1-6.

Guan, H.; Wittenberg, K. M.; Ominski, K. H. and Krause, D. O. 2006. Efficacy of ionophores in cattle diets for mitigation of enteric methane. Journal of Animal Science 84:1896-1906.

Herrera, J. G. and García, C. 2010. Bioestadística en Ciencias Veterinarias, Procedimientos de análisis de datos con SAS. 1.ed. Editorial Universidad Complutense de Madrid, Madrid.

Johnson, M. C.; Devine, A. A.; Ellis, J. C.; Grunden, A. M. and Fellner, V. 2009. Effects of antibiotics and oil on microbial profiles and fermentation in mixed cultures of ruminal microorganisms. Journal of Dairy Science 92:4467-4480.

Kim, D. H.; Mizing, K. M.; Kube, J. C.; Friesen, K. G.; McLeod, K. R. and Harmon, D. L. 2014a. Influence of monensin and lauric acid distillate or palm oil on in vitro fermentation kinetics and metabolites produced using forage and high concentrate substrates. Animal Feed Science and Technology 189:19-29.

Kim, M.; Eastridge, M. L. and Yu, Z. 2014b. Investigation of ruminal bacterial diversity in dairy cattle fed supplementary monensin alone and in combination with fat, using pyrosequencing analysis. Canadian Journal of Microbiology 60:65-71.

Lee, R. H. A.; Mendoza, G. D. and Gonzalez, S. S. 2012. Effect of calcium propionate and sorgum level on lamb performance. Animal Feed Science and Technology 177:237-241.

Mackie, R. I.; Gilchrist, F. M. C. and Heath, S. 1984. An in vivo study of ruminal microorganisms influencing lactate turnover and its contribution to volatile fatty acid production. Journal of Agricultural Science 103:37-51.

Mendoza, G. D.; Britton, R. A. and Stock, R. A. 1993. Influence of ruminal protozoa on site and extent of starch digestion and ruminal fermentation. Journal of Animal Science 71:1572-1578.

Mendoza, G. D.; Britton, R. A. and Stock, R. A. 1999. Effect of feeding mixtures of high moisture corn and dry-rolled grain sorghum on ruminal fermentation and starch digestion. Small Ruminant Research 32:113-118. 
Menke, K. H. and Steingass, H. 1988. Estimation of the energetic feed value obtained from chemical analysis and in vitro gas production using rumen fluid. Animal Research Development Journal 27:7-55.

Meyer, N. F.; Erickson, G. E.; Klopfenstein, T. J.; Greenquist, M. A.; Luebbe, M. K.; Williams, P. and Engstrom, M. A. 2009. Effect of essential oils, tylosin, and monensin on finishing steer performance, carcass characteristics, liver abscesses, ruminal fermentation, and digestibility. Journal of Animal Science 87:2346-2354.

Miranda, L. A.; Lee, R. H. A.; Mendoza, M. G. D.; Crosby, G. M. M; Relling, A. E.; Pinos, R. J. M.; Rojo, R. R. and González, M. 2016. Influence of calcium propionate on in vitro fermentation of sorghum-based diets. Revista de la Facultad de Ciencias Agrarias. Universidad Nacional de Cuyo. Available at: $<$ http://revista.fca. uncu.edu.ar/>. Accessed on: Apr. 26, 2017.

Moss, R. A.; Jouany, J. P. and Newbold, J. 2000. Methane production by ruminants: its contribution to global warming. Annales de Zootechnie 49:231-253.

Pinos, R. J. M.; González, S.; Mendoza, G. D.; Bárcena, G. R. and Martínez, G. A. 2002. Análisis estadísticos de experimentos de digestibilidad in vitro con forrajes. Interciencia 27:143-146.

Pitt, R. E.; Cross, T. L.; Pell A. N.; Shofield P. and Doane P. H. 1999. Use of in vitro gas production models in ruminal kinetics. Mathematical Biosciences 159:145-163.

Russell, B. J. and Strobel, J. H. 1989. Effect of ionophores on ruminal fermentation. Applied Environmental Microbiology 55:1-6.
Sall, J.; Lehman A.; Stephens M. and Creighton, L. 2012. JMP® Start Statistics: A guide to statistics and data analysis. 5th ed. SAS Institute Inc, Cary, NC, USA.

Shelling, T. G. 1984. Monensin mode of action in the rumen. Journal of Animal Science 58:1518-1527.

Singh, F. P. and Mohini, M. 1999. Effect of different levels of rumensin in diet on rumen fermentation, nutrient digestibility and methane production in cattle. Asian-Australasian Journal Animal Science 12:1215-1221.

Smith, D. R.; DiLorenzo, N.; Leibovich, J.; May, M. L.; Quinn, M. J.; Homm, J. W. and Galyean, M. L. 2010. Effects of sulphur and monensin concentrations on in vitro dry matter disappearance, hydrogen sulphide production, and volatile fatty acid concentrations in batch culture ruminal fermentations. Journal of Animal Science 88:1503-1512.

Van Soest, P. J.; Robertson, J. B. and Lewis, A. B. 1991. Symposium: carbohydrate methodology, metabolism, and nutritional implications in dairy cattle. Methods for dietary fibre neutral detergent fibre and non-starch polysaccharides in relation to animal nutrition. Journal of Dairy Science 74:3583-3597.

Wang, Y.; Zhang, Y.; Wang, J. and Meng, L. 2009. Effects of volatile fatty acid concentrations on methane yield and methanogenic bacteria. Biomass and Bioenergy 33:848-853.

Young, L. S.; Moon, L. S.; Bae, Y. C.; Keun, K. D.; Cheol, L. S.; Hyun, K. C. and Seo, S. 2011. Glycerol as a feed supplement for ruminants: In vitro fermentation characteristics and methane production. Animal Feed Science and Technology 166-167:269-274. 